\title{
Recognizing Autoimmune-Mediated Encephalitis in the Differential Diagnosis of Limbic Disorders
}

\author{
(D) A.J. da Rocha, (D) R.H. Nunes, A.C.M. Maia Jr, and L.L.F. do Amaral
}

\begin{abstract}
SUMMARY: Limbic encephalitis is far more common than previously thought. It is not always associated with cancer, and it is potentially treatable. Autoantibodies against various neuronal cell antigens may arise independently or in association with cancer and cause autoimmune damage to the limbic system. Neuroimaging plays a key role in the management of patients with suspected limbic encephalitis by supporting diagnosis and excluding differential possibilities. This article describes the main types of autoimmune limbic encephalitis and its mimic disorders, and emphasizes their major imaging features.
\end{abstract}

ABBREVIATIONS: AME = autoimmune-mediated encephalopathy; AMPAR $=\alpha$-amino-3-hydroxy-5-methyl-4-isoxazolepropionic acid; CASPR2, contactin-associated protein-like 2; GAD65 = 65-kD isoform of glutamic acid decarboxylase; GABA = gamma-aminobutyric acid; HSE $=$ herpes virus encephalitis; LE = limbic encephalitis; LGII = leucine-rich glioma inactivated 1; PLE = paraneoplastic limbic encephalitis; TL = temporal lobe; VGKC = voltage-gated potassium channel

L imbic encephalitis (LE) was initially described in 3 patients with malignancies (and in the absence of a better explanation) as a subacute encephalitis of later adult life that mainly affected the limbic areas. ${ }^{1}$ More than half a century later, most forms of LE have been recognized as a potentially treatable nonparaneoplastic autoimmune encephalopathy with a broad spectrum of recognizable symptoms that include psychiatric or behavioral features, seizures, hallucinations, and cognitive abnormalities. ${ }^{2,3}$

Current knowledge has improved our recognition of the neurologic presentation and outcomes of patients with LE. Early diagnosis is always desirable because a satisfactory response to immunotherapy can be achieved. ${ }^{3}$ On electroencephalography or MR imaging, most patients with LE present inflammatory features in the CSF associated with temporal lobe (TL) abnormalities and detectable antineuronal antibodies. ${ }^{3,4}$ However, LE is not the first diagnosis in clinical practice because clinical and paraclinical markers are often unavailable. In addition, symptoms can precede the diagnosis of cancer, and T2/FLAIR hyperintensity in the medial aspect of the TL may mimic several other disorders. ${ }^{4-12}$

From the Division of Neuroradiology (A.J.d.R., R.H.N., A.C.M.M., L.L.F.d.A.), Santa Casa de São Paulo School of Medical Sciences, São Paulo, Brazil; Division of Neuroradiology (A.J.d.R., R.H.N., A.C.M.M.), Fleury Medicina e Saúde, São Paulo, Brazil; Research Fellow, University of North Carolina (R.H.N.), Chapel Hill, North Carolina; and Division of Neuroradiology (L.L.F.d.A.), Med Imagem, Hospital da Beneficência Portuguesa de São Paulo, São Paulo, Brazil.

Please address correspondence to Antonio Jose da Rocha, MD, PhD, Santa Casa de Misericórdia de São Paulo - Serviço de Diagnóstico por Imagem, Rua Dr Cesário Motta Junior 112, Vila Buarque, São Paulo - SP, Brazil 01221-020; e-mail: renatohn@hotmail.com

- Indicates open access to non-subscribers at www.ajnr.org

http://dx.doi.org/10.3174/ajnr.A4408
MR imaging plays a key role in the management of patients with suspected LE and is used as part of the LE diagnostic criteria to rule out differential diagnoses. Certain imaging and clinical peculiarities may narrow the list of possible diagnoses; however, a complete list of differential diagnoses remains beyond the scope of this article. Our current aim was to describe the most commonly reported MR features of LE and its mimic disorders.

\section{Autoimmune Encephalopathies}

Both paraneoplastic LE (PLE) and nonparaneoplastic LE present a similar clinical picture that includes CSF and MR imaging abnormalities. It is estimated that $60 \%$ to $70 \%$ of cases are PLE; however, a neurologic disorder can precede neoplasia by months or even years. ${ }^{2,3}$

Autoimmune-mediated encephalopathy (AME) can be distinguished by its association with autoantibodies ${ }^{3,13}$ and by certain recognizable features on MR imaging, which (besides LE) include cerebellar degeneration, striatal encephalitis, brain stem encephalitis, and leukoencephalopathy. ${ }^{14-16}$ A comprehensive search for an underlying malignancy is always considered when AME is suspected. ${ }^{3}$ The position of the causal antigens is correlated with the disease mechanism and with concurrent cancer. ${ }^{2,3,13}$ In general, antibodies against intracellular antigens are associated with cytotoxic T-cell mechanisms; in these cases, neuronal damage seems to be irreversible, associations are found with underlying malignancies and poor prognosis, and structural abnormalities are not restricted to the limbic structures. ${ }^{10}$ Conversely, in restricted LE, neuronal cell-surface antigens are targeted, an associated malignancy is unusual, and its expected response to immunotherapy is superior. ${ }^{3}$ 

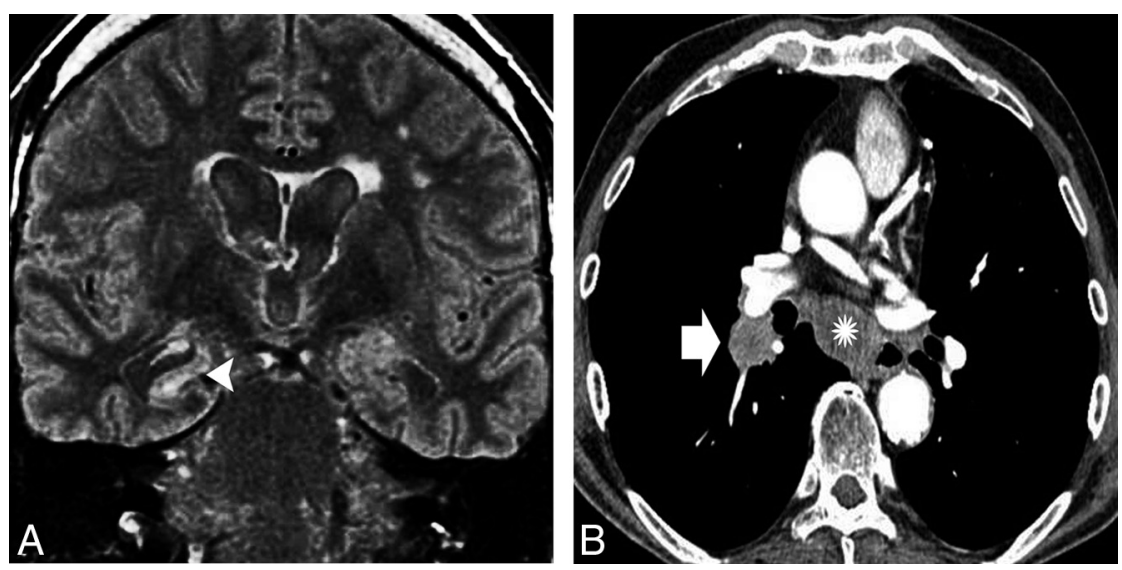

FIG 1. A 62-year-old man with subacute cognitive impairment and seizures. $A$, An enlarged and hyperintense right hippocampus in a coronal FLAIR image (arrowhead). Additional right amygdala involvement was observed, but no abnormal enhancement was documented after intravenous gadolinium administration (not shown). B, Body CT after contrast administration shows a right hilar mass (arrow) with an enlarged lower paratracheal lymph node (asterisk). Endobronchial biopsy specimen revealed an small cell lung carcinoma, and the diagnosis was consistent with PLE.

\section{Paraneoplastic LE}

The classic mechanism reported in PLE is a systemic neoplasia that expresses coincident antigens within the CNS, which results in the production of antibodies that target neoplastic tissue (onconeural antigens) as well as intracellular antigens. ${ }^{2,13,14}$ The correct diagnosis of PLE is relevant because earlier recognition often allows the discovery and treatment of the underlying malignancy. Cancer control is a crucial step in the management of PLE, which is usually followed by the remission of the paraneoplastic syndrome. ${ }^{17}$

\section{PLE Associated with Autoantibodies against Intracellular Antigens}

Hu Antibodies. The $\mathrm{Hu}$ antineuronal nuclear antibody is a type IIa antineuronal nuclear antibody type I, which can appear in any part of the nervous system. Approximately $75 \%$ of the patients have small cell lung carcinoma and often develop symptoms related to inflammation across widespread areas of the CNS or the peripheral nervous system. ${ }^{18} \mathrm{MR}$ imaging reveals variable abnormalities according to clinical features, including T2/FLAIR hyperintensity in the mesial TL (Fig 1), cerebellar edema or atrophy, and brain stem abnormalities. ${ }^{4}$ Rarely, patients have epilepsia partialis continua, which results from restricted lesions in nonlimbic cortical areas. ${ }^{19}$ First-line immunotherapies often fail, and the prognosis of this condition is usually poor despite immunotherapy. ${ }^{20}$

Ma2 Antibodies. Patients with Ma2 antineuronal nuclear antibody-related encephalitis often have accompanying symptoms of diencephalic inflammation (sleep disturbances, dysthermia, and endocrine abnormalities) and upper brain stem inflammation (eye movement abnormalities and hypokinetic syndrome). Approximately $75 \%$ of patients have abnormal MRI, usually with classic LE findings. ${ }^{21}$ The remaining patients have signal abnormalities that are either isolated or associated with the hypothalamus and thalamus or with the brain stem. ${ }^{22}$ Nodular parenchymal enhancement in the affected regions has been reported, which may mimic a brain tumor or an infection. ${ }^{21,22}$ This AME occurs mostly in association with testicular germinal cell tumors in younger male individuals; but, in older individuals, there may be an underlying nonsmall cell lung carcinoma or breast cancer. ${ }^{23}$ Improvement with immunotherapy is more likely than in other forms of LE that involve antibodies against intracellular antigens. ${ }^{22}$

CV2/Collapsing Response Mediator Protein-5 Antibodies. Bilateral striatal encephalitis with T2/FLAIR hyperintensity is a typical finding, which causes choreiform movement disorders and is highly suggestive of CV2/collapsing response mediator protein-5 antineuronal nuclear antibody-related encephalitis associated with underlying small cell lung carcinoma or malignant thymoma, among others disorders. ${ }^{24,25}$ However, patients may also present with a range of imaging patterns that rarely include LE and typically do not include striatal restriction on DWI, which may help to distinguish this AME from prion diseases. $^{25}$

\section{PLE Associated with Autoantibodies against Extracellular Antigens}

N-Methyl-D-Aspartate Receptor Antibodies. A specific immunoglobulin $\mathrm{G}$ antibody against the GluN1 subunit of the anti-Nmethyl-D-aspartate receptor results in a highly characteristic and recognizable LE that is far more common than previously believed $^{26}$ and mostly affects young women and children. ${ }^{27}$ Two major well-characterized stages are noticeable. ${ }^{28}$ A viral-like prodrome followed by severe psychiatric features characterizes the earliest involvement of the cortical regions. In addition, patients may develop amnesia and seizures. ${ }^{29}$ After a few days to a few weeks, subcortical areas are affected and a movement disorder appears (often dyskinesia of the mouth and face) followed by a decreased level of consciousness and dysautonomia, which requires intensive care support. A lymphocytic pleocytosis is observed in the CSF, and, less commonly, increased protein and/or oligoclonal bands are present. ${ }^{27}$

The most common MR imaging abnormality is unilateral or bilateral LE ${ }^{30,31}$; however, approximately $66 \%$ of patients have an unremarkable MR imaging. Cerebellitis, striatal abnormalities, and brain stem encephalitis have also been described. ${ }^{30,31}$ Gadolinium enhancement is uncommon, and imaging follow-up could reveal complete recovery or focal atrophy (Fig 2). ${ }^{27,30,31}$

The concurrence of tumors is reportedly age dependent. Whereas approximately $45 \%$ of adult woman had ovarian teratoma, only $9 \%$ of younger girls had this type of tumor. Identification and removal of the tumor were crucial because patients without tumor removal recovered less frequently and had an increased risk of relapse. ${ }^{27}$ In patients older than 45 years, the outcome was reportedly favorable, whereas $23 \%$ of patients had underlying carcinomas instead of teratomas. ${ }^{32}$ Despite this ominous AJNR Am J Neuroradiol 36:2196-205 Dec 2015 www.ajnr.org 

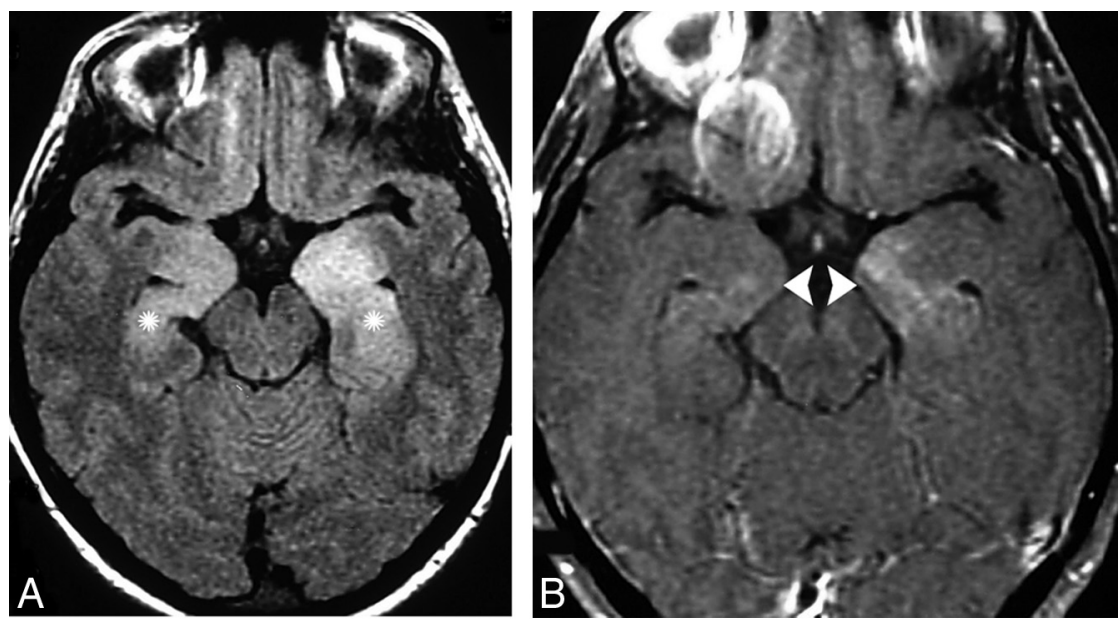

rapidly progressive encephalopathy with refractory seizures, status epilepticus, and/or epilepsia partialis continua that was preceded by or associated with behavioral changes. ${ }^{37}$ Unlike patients with other LEs in whom MR imaging is either normal or shows predominant involvement of the limbic system, these patients have multifocal and extensive T2/FLAIR brain abnormalities. In addition, they respond well to immunotherapy and rarely have an underlying tumor. When a tumor is present, it is usually a thymoma. Patients are often misdiagnosed with the $65-\mathrm{kD}$ isoform of glutamic acid decarboxylase (GAD65)
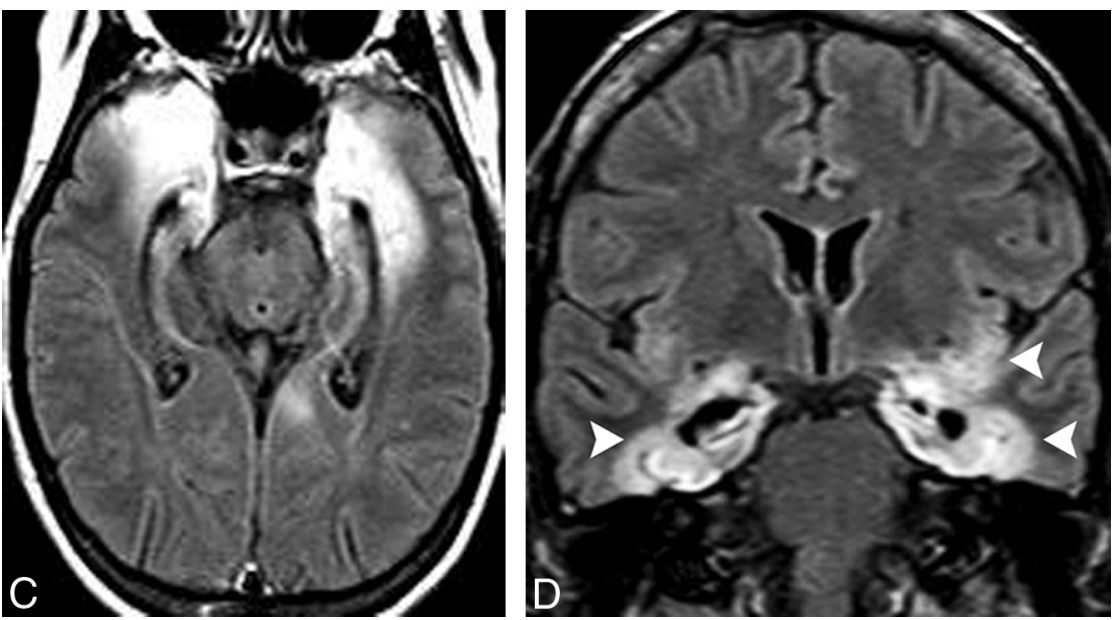

FIG 2. A previously healthy 44-year-old woman presented with subacute psychiatric disturbance with no fever or seizures. A, Bilateral and asymmetric hyperintensity was observed on an axial FLAIR image in the enlarged amygdalae and hippocampi (asterisks), predominantly on the left side. $B$, A faint ill-defined enhancement of the left hippocampus was documented on an axial $\mathrm{Tl}$ postcontrast image (arrowheads). Autoimmune encephalitis was considered, and the presence of anti-N-methyl-D-aspartate receptor autoantibodies was confirmed. $C$ and $D$, Imaging follow-up revealed signal abnormalities and atrophy on FLAIR that involved the hippocampus, amygdala, parahippocampal gyrus, and left insula (arrowheads), compatible with severe sequelae. antibody-associated encephalitis or Hashimoto encephalitis due to the frequent co-occurrence of GAD65 and antithyroid antibodies. ${ }^{16,37}$

Other PLEs with Autoantibodies against Extracellular Antigens. In anti- $\alpha$-amino3-hydroxy-5-methyl-4-isoxazolepropionic acid receptor (AMPAR) encephalitis, patients develop antibodies against the GluR1 and GluR2 subunits of the AMPAR, and present with symptoms and MR imaging features of unilateral or bilateral LE that rarely involve extrahippocampal limbic structures. In some cases, the manifestations are purely psychiatric. Most of these patients are women who are harboring a tumor in the lung, breast, or thymus. $^{38}$

Hodgkin lymphoma is the third most common cause of LE after small cell lung carcinoma and testicular germ cell tumors. ${ }^{4}$ This association has been

clinical presentation, approximately $50 \%$ of patients respond to first-line immunotherapies, often with full remission, whereas patients who do not respond to treatment or who experience relapse should be reassessed for the presence of an underlying contralateral or recurrent teratoma. ${ }^{33}$

Gamma-Aminobutyric Acid Receptor Antibodies. Anti-gamma-aminobutyric acid (GABA) B-receptor antibody-related encephalitis usually presents as LE. Most patients have early and frequent seizures associated with unilateral or bilateral T2/FLAIR hyperintensity in the mesial TL that are potentially reversible after treatment. ${ }^{34}$

As is most commonly reported in older patients, approximately $50 \%$ of patients with GABA B-receptor AMEs have underlying small cell lung carcinoma or lung neuroendocrine tumors. ${ }^{35}$ This AME usually precedes a cancer diagnosis but represents the second most common cause of LE related to small cell lung carcinoma. $^{36}$

An AME associated with anti-GABA A-receptor antibodies was recently described in children and adults who developed a called Ophelia syndrome, and it is characterized by generalized or partial complex seizures in $50 \%$ of the patients. It is also more commonly associated with short-term memory loss or amnesia, psychiatric changes, and even frank psychosis with visual or auditory hallucinations or paranoid ideation. ${ }^{17,39}$

Intriguingly, AME is not typically associated with non-Hodgkin lymphoma. ${ }^{17}$ Although Hodgkin lymphoma rarely infiltrates the CNS, the onset of an LE in this setting should be attributable to either a concurrent infection or an AME (Fig 3). Successful treatment of the tumor results in complete neurologic recovery, probably due to an association with an antibody against the metabotropic glutamate receptor 5, which is highly expressed in the hippocampus and presumably promotes reversible neuronal dysfunction rather than neuronal death. ${ }^{17,40}$

\section{Nonparaneoplastic LE}

It is assumed that nonparaneoplastic LE is more common than classic PLE and affects a wider age range of patients, though predominantly young patients. Nonparaneoplastic LE is a re- 

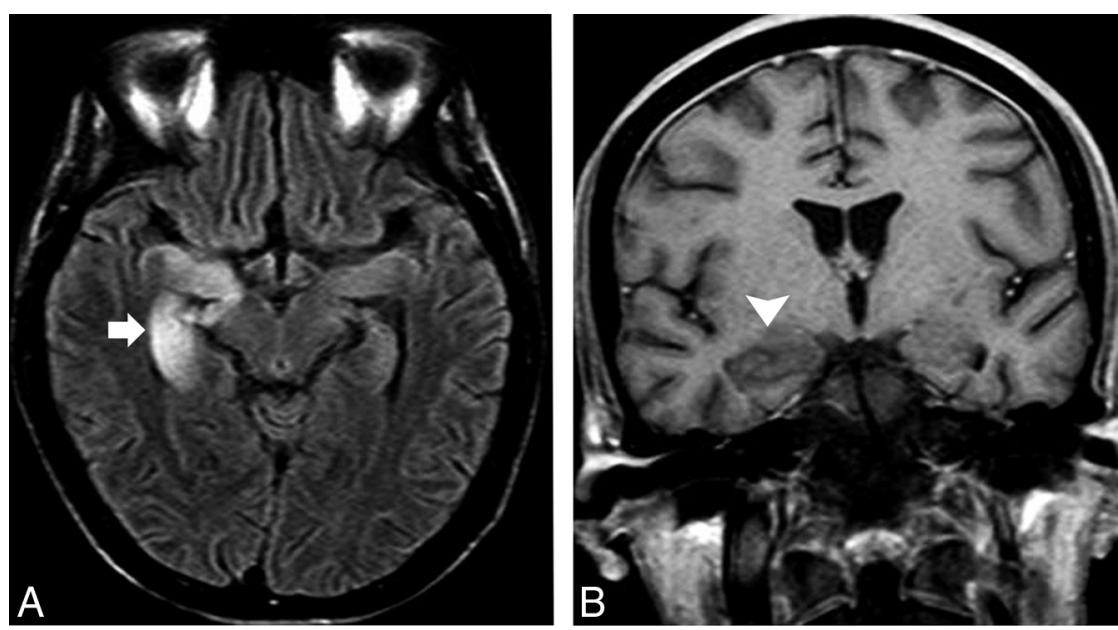

FIG 3. A 22-year-old man with Hodgkin lymphoma presented with acute onset of short-term memory loss and mental confusion. $A$, An evident hyperintensity and subtle enlargement of the right hippocampus and amygdala were noticed on an axial FLAIR image (arrow). B, No parenchymal enhancement was observed (arrowhead). In addition to the fact that CNS involvement is not expected in Hodgkin lymphoma, a lack of enhancement is not the expected imaging pattern. After the patient did not respond to antiviral treatment, PLE was considered. The findings fulfilled the criteria for Ophelia syndrome, which consists in an interval of $<4$ years between the onset of neuropsychiatric disturbance and the diagnosis of the Hodgkin lymphoma, exclusion of other cancer-related complications, and evidence of hippocampal abnormalities on MR imaging.
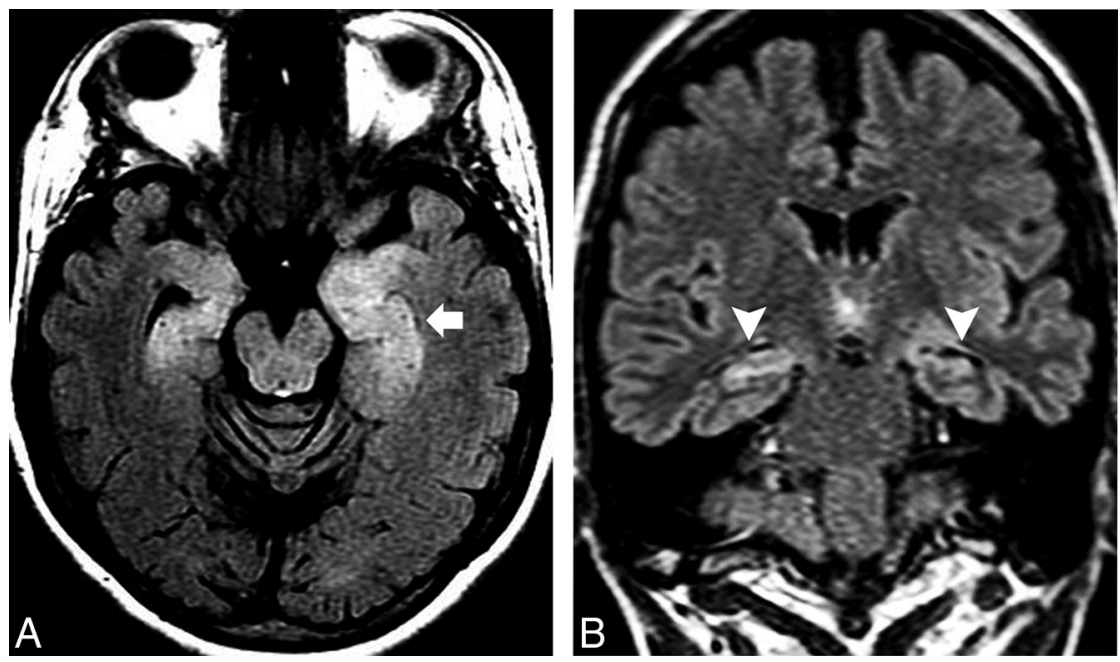

FIG 4. A 38-year-old woman presented with personality and behavioral changes associated with progressive drug-resistant epilepsy. Memory testing revealed an anterograde episodic memory disorder, and electroencephalography showed TL epileptiform discharges. A, A selective hyperintensity in the hippocampi that extended to the amygdalae bilaterally was noticed on an axial FLAIR image, predominantly on the left side (arrow). B. Imaging follow-up revealed bilateral hippocampal sclerosis, which is shown in a coronal FLAIR image (arrowheads). Whole-body $\mathrm{PET} / \mathrm{CT}$ and pelvic sonography were unremarkable (not shown). Autoimmune encephalitis was suggested, and a high titer of GAD65 antibodies was confirmed.

sult of antibodies against neuronal cell surface or synaptic receptors. ${ }^{2}$

\section{Nonparaneoplastic LE Associated with Autoantibodies against Intracellular Antigens}

GAD65 Antibodies. Some patients with nonparaneoplastic LE have antibodies against the intracellular antigen GAD65. However, unlike other intracellular antibodies, anti-GAD65 is not typically related to underlying malignancies. Patients typically present with stiff man syndrome or cerebellar ataxia, but they also may present with severe TL epilepsy, with less pronounced cognitive-behavioral features and a poorer response to first-line epilepsy drugs. ${ }^{41}$

MR imaging frequently shows signal abnormalities and swelling predominantly in the amygdala and hippocampus, which may resolve or progress to mesial temporal sclerosis on follow-up imaging (Fig 4). ${ }^{41}$

\section{Nonparaneoplastic LE Associated with Autoantibodies against Extracellular Antigens}

Voltage-Gated Potassium ChannelComplex Antibodies. Anti-leucinerich glioma inactivated 1 (LGI1) and anti-contactin-associated protein-like 2 (CASPR2) antibodies have been described as voltage-gated potassium channel (VGKC) antibodies and the most common cause of nonparaneoplastic LE. ${ }^{16}$ Results of recent studies highlight the relevance of discriminating both LGI1 and CASPR2 from VGKCcomplex antibodies. Although LGI1 and contactin-associated protein-like 2 antibodies are specifically associated with limited subsets of syndromes, VGKCcomplex antibodies lack specificity and may be found in nonautoimmune diseases, including Creutzfeldt-Jakob disease. $^{42,43}$

LGI1 antibodies occur most often in young male patients (2:1) who develop a classic LE with peculiar features, such as hyponatremia (60\%), rapid eye movement-sleep behavior disorders, and normal CSF. In a few patients, a characteristic clinical manifestation described as faciobrachial dystonic or tonic seizures is observed. Fewer than $10 \%$ of patients with LGI1 antibodies have an underlying neoplasm, which is usually a thymoma. ${ }^{16,44}$

Approximately $78.6 \%$ of patients present with typical LE MR imaging findings (Fig 5). Restricted DWI is observed in approximately $50 \%$ of these patients, whereas up to $25 \%$ have associated mild, ill-defined contrast enhancement and extrahippocampal involvement, including striatal encephalitis. ${ }^{11,45}$

Antibodies against the VGKC-complex have been identified in a subgroup of patients with epilepsy that appears on imaging as mesial temporal sclerosis, which indicates that some patients with epilepsy who are poorly responsive to conventional antiepileptic drugs may have an immune-mediated etiology. ${ }^{11,46}$ Recognition and appropriate treatment with immunotherapy are recom- 
mended to prevent structural damage due to severe encephalitis as well as cognitive dysfunction. ${ }^{16,47}$

LGI1 antibodies are almost exclusively expressed in the CNS. They often result in LE or epilepsy but primarily result in nonparaneoplastic LE (Fig 5). Conversely, CASPR2 antibodies expressed in the peripheral nervous system are involved in Morvan disease or peripheral nerve hyperexcitability-neuromyotonia spectrum disorders and are typically associated with thymomas. Myasthenia gravis and LE can also be found in some patients. ${ }^{48}$

\section{Limbic Disorders That Mimic AME}

Abnormal MR signal intensity that involves the TL has a broad differential diagnosis that includes a range of unrelated disorders that are rarely reported, for example, Whipple disease, ${ }^{49} 4$-aminopyri-
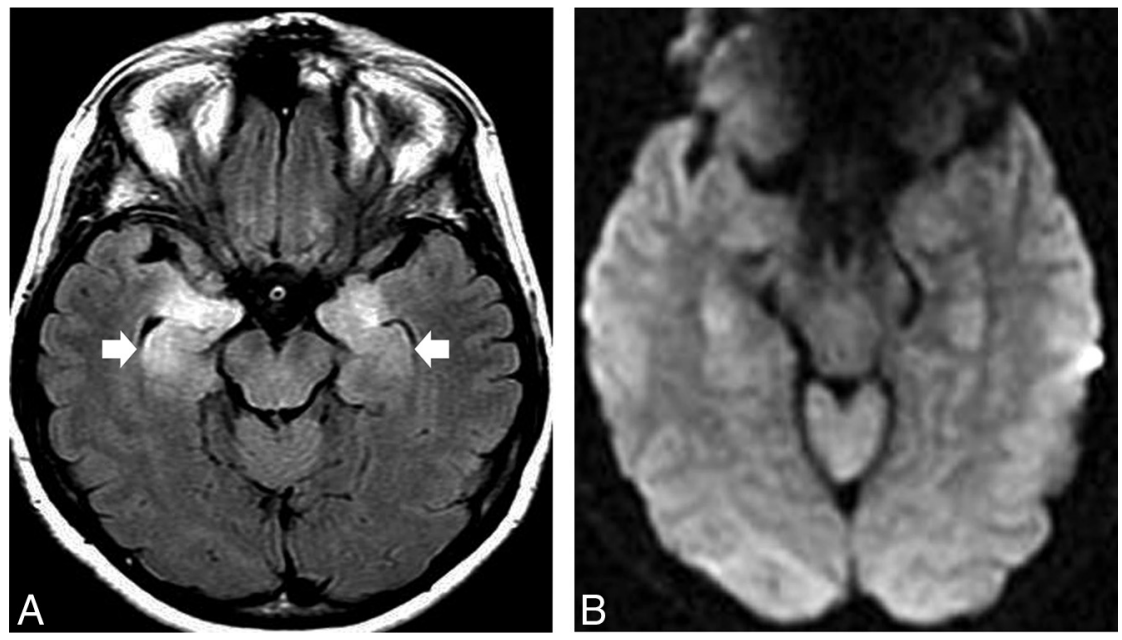

FIG 5. A healthy 46-year-old woman presented with an acute onset of psychiatric disturbance and hyponatremia. A, Bilateral hyperintensity and mild enlargement were noticed on an axial FLAIR image in both hippocampi and amygdalae. $B$, No abnormal restricted diffusion was observed on DWI. The final diagnosis was anti-VGKC encephalitis. Restricted diffusion may occur in approximately $50 \%$ of patients at this phase and is usually restricted to the limbic system. The presence of faciobrachial dystonic or tonic seizures, hyponatremia, and unremarkable CSF in the setting of LE should raise concern that anti-LGIl encephalitis is present.
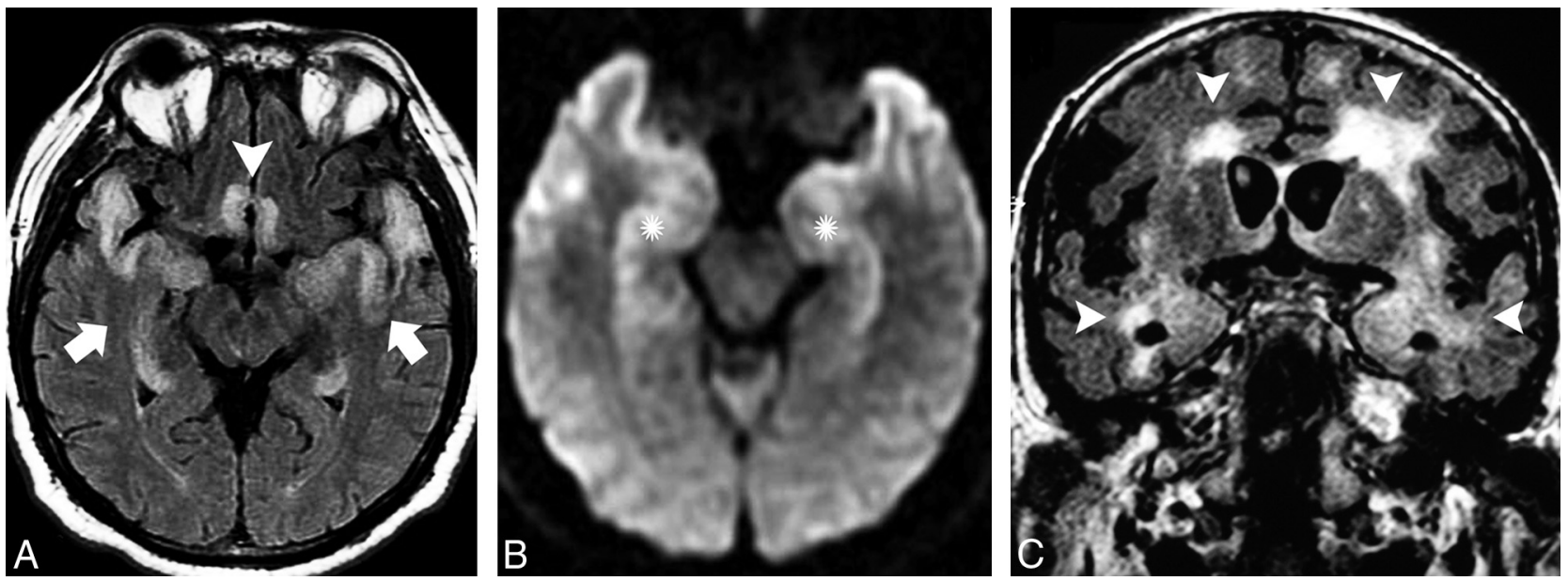

FIG 6. A 47-year-old man with HSE. A, Bilateral symmetric cortical swelling and hyperintensity on axial FLAIR were observed in the anteromedial TLs (arrows) and also affected the insular cortex and rectus gyri (arrowhead). B, Restricted diffusion was documented in the same areas on DWI (asterisks). Bilateral and usually asymmetric involvement of the limbic system sparing the basal ganglia in the setting of acute LE should raise concerns for HSE. The presence of hemorrhagic foci and gyriform enhancement are also of diagnostic value in more-advanced disease. C, A similar pattern with bilateral asymmetrical involvement of the anteromedial TLs (arrows) on coronal FLAIR was observed in addition to the extensive white matter changes (arrowheads) in a 59-year-old man with progressive dementia who was later diagnosed with neurosyphilis.
HSE. The absence of psychiatric symptoms and the sudden and rapid progression also support the early administration of antiviral therapy based on a presumed diagnosis of HSE. ${ }^{10}$ In addition, even though both HSE and LE involve the TL, basal ganglia involvement on MR imaging favors nonherpetic etiologies. $^{12}$

It has been demonstrated that some types of viral encephalitis can trigger autoimmune LE, ${ }^{53,54}$ particularly anti- $N$ methyl-D-aspartate receptor encephalitis. ${ }^{55}$ This phenomenon occurs when prolonged or atypical neurologic symptoms recur after successful control of the viral infection. Some patients with negative viral results develop a syndrome described as relapsing post-HSE or choreoathetosis post-HSE. A few weeks after recovery from HSE, children present with abnormal movement and adults 

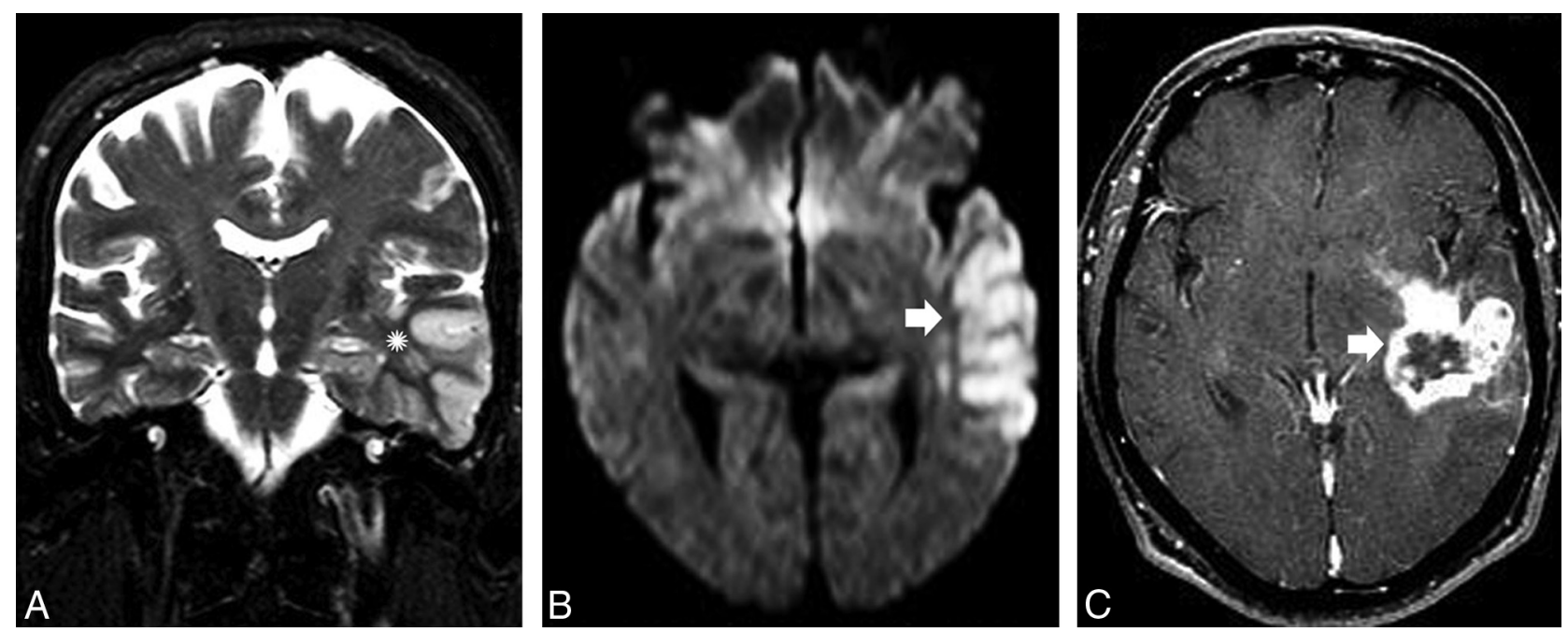

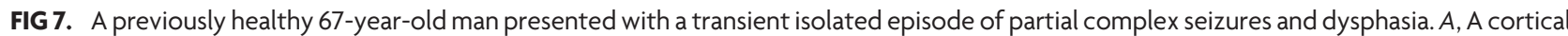
abnormality that involved the lateral aspect of the left TL (asterisk) and a subtle hyperintensity on coronal T2 were noticed in the ipsilateral hippocampus. B, Restricted diffusion on DWI was visible in the same areas (arrowhead), and a diagnosis of postictal edema was considered. C, After 2 months and a worsening of the clinical manifestations, a necrotic mass in the left TL (arrow) was observed on a Tl postcontrast image. A diagnosis of glioblastoma was confirmed after surgery. High-grade gliomas can manifest early as ill-defined lesions that usually have restricted diffusion and involve the cortex with a lack of a mass effect. Follow-up imaging and advanced imaging techniques are crucial for making the diagnosis.
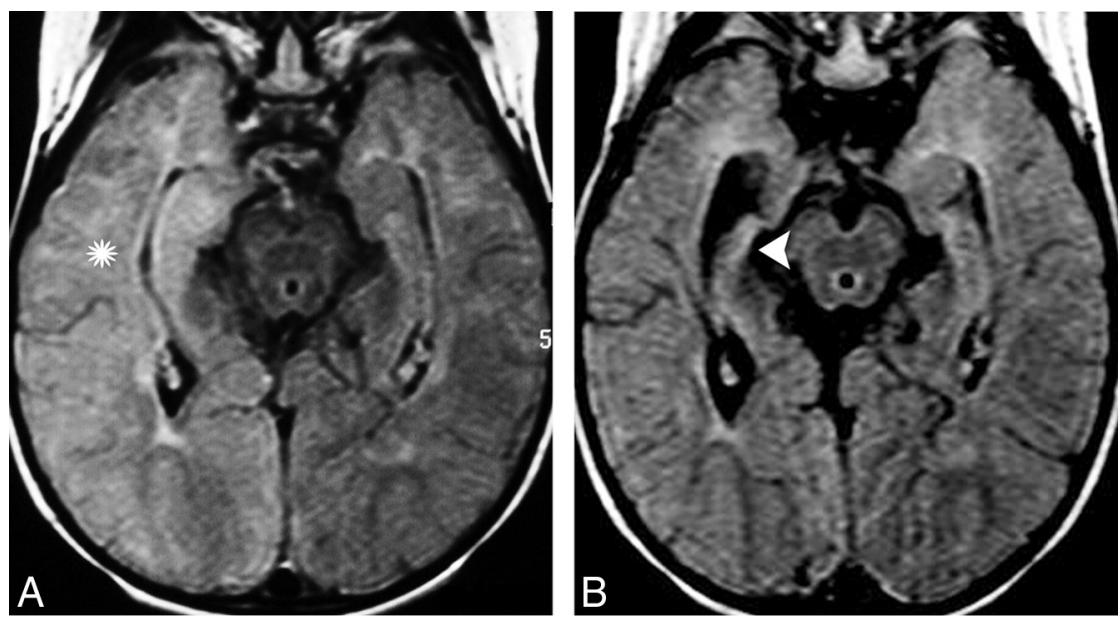

FIG 8. A 15-month-old child presented with a prolonged generalized tonic-clonic seizure episode. A, Extensive hyperintensity on an axial FLAIR image that involves the cortex and the white matter of the right TL (asterisk) indicated postictal edema. B, Comparative FLAIR imaging results on follow-up after 6 months are consistent with right mesial temporal sclerosis (arrowhead) in this patient who developed chronic epilepsy.

present with behavioral changes that are not associated with additional brain lesions on MR imaging or response to antiviral therapy.

Neurosyphilis. The incidence of neurosyphilis, caused by a spirochete (Treponema pallidum), has once again begun to increase in the era of acquired immunodeficiency syndrome. ${ }^{56} \mathrm{MR}$ imaging shows a variety of usually nonspecific findings, including selective involvement of the TL that mimics HSE and LE. ${ }^{10,56}$ In older subjects with a long latency period of infection or in patients who are immunocompromised, T2/FLAIR hyperintensities in the mesial TL areas that may or may not be associated with either atrophic or gadolinium-enhanced areas increase the likelihood that neurosyphilis is present rather than other etiologies (Fig 6).

\section{Neoplastic Limbic Disorders}

Diffuse gliomas and gliomatosis cerebri may mimic the imaging features of LE. The hallmark feature on MR imaging is an infiltrative pattern with poorly demarcated boundaries that is usually not restricted to the limbic system. . $^{8,14,57}$ Gliomatosis cerebri, as well as low-grade diffuse gliomas, may progress slowly, with seizures or even focal deficits. Moreover, high-grade tumors might present with atypical imaging features that rarely mimic LE but then progress invariably to a recognizable MR imaging pattern of necrotic lesions (Fig 7). In this setting, MR-perfusion and MR-spectroscopy techniques are useful to detect brain tumors and enable surgical planning. ${ }^{58}$

\section{Vascular Limbic Disorders}

Differentiation between primary vasculitis and LE may represent a real challenge under certain conditions of subacute presentation. Abnormal vessels on angiography and cytotoxic edema on DWI that usually extends throughout the compromised vascular territory and is not restricted to the limits of the limbic system are helpful to confirm imaging suspicions. ${ }^{9}$ Transient global amnesia also affects the hippocampal formation, but its clinical and imaging presentation is rather typical. ${ }^{59}$

\section{Seizure-Related Limbic Disorders}

Hippocampal sclerosis associated with TL abnormalities is the multifactorial hallmark of mesial temporal sclerosis. This condition could be a consequence of prolonged unilateral febrile seizures or status epilepticus, which occurs mainly in children when AJNR Am J Neuroradiol 36:2196-205 Dec 2015 www.ajnr.org 
the hippocampus is more vulnerable to convulsion-induced excitotoxic damage and involves the sectors of the hippocampus rich in kainate or $N$-methyl-D-aspartate receptors and, therefore, that lack protection against calcium overload. ${ }^{60}$

Prolonged seizures or status epilepticus may appear as TL abnormalities on MR imaging, including cortical hyperintensities on DWI that mimic LE and are attributable to hippocampal postictal edema. ${ }^{9,61}$ Imaging follow-up with typical clinical and electroencephalographic features may aid diagnosis. This condition is potentially reversible or can result in atrophy with mesial temporal sclerosis (Fig 8). ${ }^{62}$

Hippocampal sclerosis may also be related to a rare neurodegenerative condition called pure hippocampal sclerosis dementia. Despite its similarity to mesial temporal sclerosis on imaging, dementia is always observed in the absence of epilepsy and usually occurs in the elderly. ${ }^{63}$

Febrile infection-related epilepsy syndrome, or acute encephalitis with refractory repetitive partial seizures, is considered a severe epileptic encephalopathy with multifocal refractory status epilepticus, which occurs mostly in young children but also in adult patients. ${ }^{64}$ The initial phase is characterized by a simple febrile infection, followed by an acute phase with recurrent focal seizures that evolve rapidly into refractory status epilepticus, generally without fever and additional neurologic features. The diagnosis is made after an exhaustive negative search for an active CNS infection and autoimmune or metabolic disorders. Early MR imaging may be normal in approximately half of the cases; however, T2 abnormalities are detected in some patients, predominantly in the temporal regions but also in the insula and basal ganglia, which mimics LE. ${ }^{64,65}$ In the chronic phase, MR imaging shows mesial temporal sclerosis in half of the patients, and bilateral hypometabolism of orbitofrontal and temporoparietal regions is often demonstrated on PET. ${ }^{64}$ The etiology and mechanisms that underlie it are still unknown, and, even though an autoimmune mechanism could be considered and autoantibodies have previously been described in epilepsy, up to now there is no evidence to support that autoantibodies are the etiology of febrile infectionrelated epilepsy syndrome. ${ }^{64,66}$

\section{Other Autoimmune Disorders}

Autoimmune systemic disorders are associated with LE. ${ }^{2}$ Sjögren syndrome, lupus erythematosus, Beçhet disease, primary angiitis of the CNS, and antiphospholipid syndrome can occasionally cause clinical and/or radiologic abnormalities in the limbic system that are not antibody mediated but that are accompanied by histopathologic evidence of cellular inflammation. ${ }^{3}$

Hashimoto encephalopathy or steroid-responsive encephalopathy associated with autoimmune thyroiditis ${ }^{67}$ manifests as a diffuse progressive AME characterized by dementia, psychiatric disturbances, and seizures; there also is a vasculitic type characterized by multiple strokelike episodes, seizures, and fluctuating consciousness. ${ }^{68}$ This disorder is more common in women and is associated with autoimmune antithyroid antibodies. There is increasing evidence that these antibodies are not pathogenic but rather are markers of autoimmunity for other associated but currently unclassified antineuronal antibodies. ${ }^{69}$ MR imaging may mimic patterns of LE (Fig 9), ${ }^{70}$ but leukoencephalopathy with

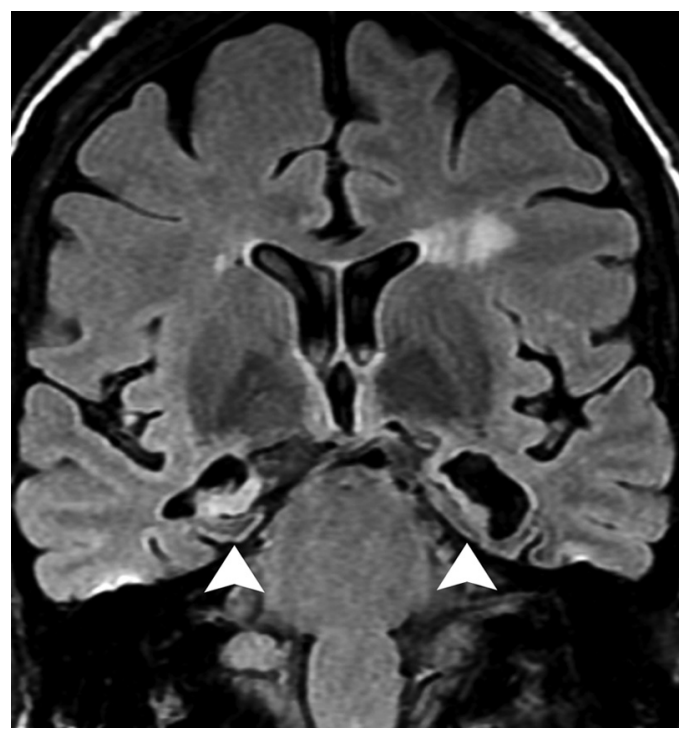

FIG 9. A 45-year-old woman presented with strokelike episodes associated with fluctuating and progressive cognitive impairment. Severe atrophy and bilateral hyperintensity in the hippocampi (arrowheads) along with mild cortical atrophy and scattered white matter changes were observed on a coronal FLAIR image. Although the patient had euthyroid status, she presented with high titers of serum antithyroperoxidase $(490 \mathrm{U} / \mathrm{mL}$; reference value, $<60$ $\mathrm{U} / \mathrm{mL}$ ). After excluding other causes, the diagnosis of steroid-responsive encephalopathy associated with autoimmune thyroiditis was considered.

bilateral patchy or confluent supratentorial subcortical and periventricular white matter T2/FLAIR hyperintensities is the most common abnormality and is usually reversible after corticotherapy. ${ }^{67}$

A rare cause of LE is relapsing polychondritis, in which clinicoradiologic involvement of the limbic system might be more common than was previously thought. ${ }^{71,72}$ This condition is a disorder of unknown etiology that manifests as episodic and progressive inflammation of the cartilaginous structures of the body, as is suggested by the detection of autoantibodies against type II collagen restricted to the cartilage in the sera of $30 \%-50 \%$ of affected patients. ${ }^{73} \mathrm{MR}$ imaging findings are coincident with LE; however, peculiar cartilage involvement may help identify this entity.

\section{Recommended Diagnostic Approach to Limbic Disorders}

An algorithm that describes an approach to the diagnosis of limbic disorders by using clinical and neuroimaging features is presented in Fig 10.

\section{CONCLUSIONS}

$\mathrm{LE}$ and the mimic disorders presented in this review have always existed. However, they have just begun to be clearly distinguished over the past decade. Their association with autoantibodies influences their prognosis and results in recognizable imaging patterns that vary according to the position of the causal antigens (intra- or extracellular) and the concurrence of cancer. Mimic disorders may represent a complication of an underlying malignancy or may occur independently. MR imaging is the best technique for 


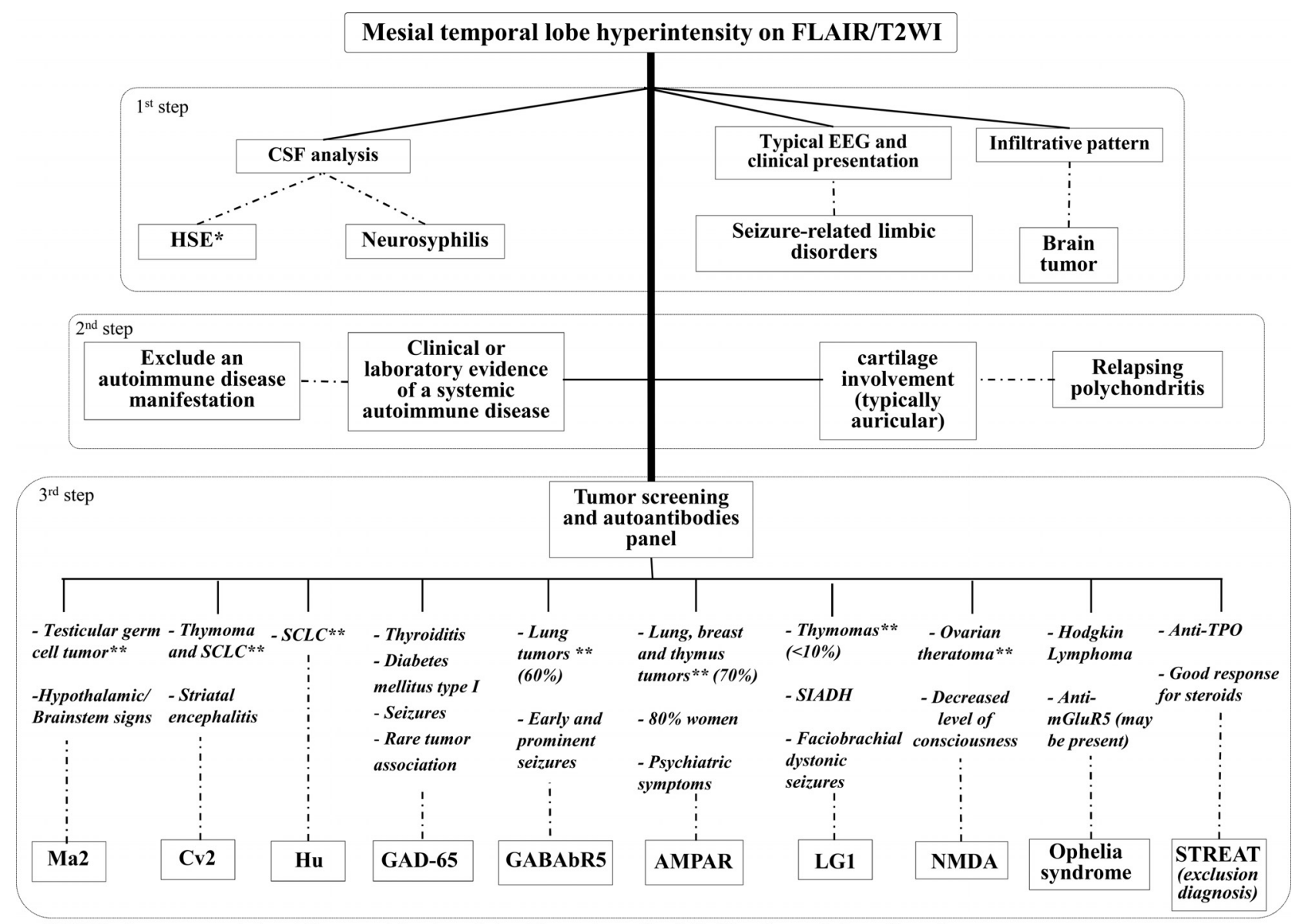

* HSE is always suspected and its prompt treatment should remain until a definitive diagnosis is confirmed.

** more commonly reported tumors.

FIG 10. Proposed approach to the diagnosis of LE and its mimic disorders. SCLC indicates small cell lung carcinoma; SIADA, syndrome of inappropriate antidiuretic hormone; TPO, thyroperoxidase; NMDA, N-methyl-D-aspartate; STREAT, steroid-responsive encephalopathy associated with autoimmune thyroiditis; AMPAR, $\alpha$-amino-3-hydroxy-5-methyl-4-isoxazolepropionic acid receptor.

recognizing limbic disorders and is useful for differentiating among them and for improving their investigation.

\section{REFERENCES}

1. Brierley JB, Corsellis JA, Hierons R, et al. Subacute encephalitis of later adult life mainly affecting the limbic areas. Brain 1960;83: 357-68 CrossRef

2. Vernino S, Geschwind M, Boeve B. Autoimmune encephalopathies. Neurologist 2007;13:140-47 CrossRef Medline

3. Tüzun E, Dalmau J. Limbic encephalitis and variants: classification, diagnosis and treatment. Neurologist 2007;13:261-71 CrossRef Medline

4. Gultekin SH, Rosenfeld MR, Voltz R, et al. Paraneoplastic limbic encephalitis: neurological symptoms, immunological findings and tumour association in 50 patients. Brain 2000;123(pt 7):1481-94 CrossRef Medline

5. Vieira Santos A, Matias S, Saraiva P, et al. Differential diagnosis of mesiotemporal lesions: case report of neurosyphilis. Neuroradiology 2005;47:664-67 CrossRef Medline

6. Kararizou E, Markou I, Zalonis I, et al. Paraneoplastic limbic encephalitis presenting as acute viral encephalitis. J Neurooncol 2005; 75:229-32 CrossRef Medline

7. Tyler KL. Emerging viral infections of the central nervous system: part 1. Arch Neurol 2009;66:939-48 CrossRef Medline

8. Nagata R, Ikeda K, Nakamura Y, et al. A case of gliomatosis cerebri mimicking limbic encephalitis: malignant transformation to glioblastoma. Int Med 2010;49:1307-10 CrossRef Medline
9. Förster A, Griebe M, Gass A, et al. Diffusion-weighted imaging for the differential diagnosis of disorders affecting the hippocampus. Cerebrovasc Dis 2012;33:104-15 CrossRef Medline

10. Armangue T, Leypoldt F, Dalmau J. Autoimmune encephalitis as differential diagnosis of infectious encephalitis. Curr Opin Neurol 2014;27:361-68 CrossRef Medline

11. Kotsenas AL, Watson RE, Pittock SJ, et al. MRI findings in autoimmune voltage-gated potassium channel complex encephalitis with seizures: one potential etiology for mesial temporal sclerosis. AJNR Am J Neuroradiol 2014;35:84-89 CrossRef Medline

12. Oyanguren B, Sánchez V, González FJ, et al. Limbic encephalitis: a clinical-radiological comparison between herpetic and autoimmune etiologies. Eur J Neurol 2013;20:1566-70 CrossRef Medline

13. Dalmau J, Bataller L. Clinical and immunological diversity of limbic encephalitis: a model for paraneoplastic neurologic disorders. Hematol Oncol Clin North Am 2006;20:1319-35 CrossRef Medline

14. Demaerel P, Van Dessel W, Van Paesschen W, et al. Autoimmunemediated encephalitis. Neuroradiology 2011;53:837-51 CrossRef Medline

15. Darnell RB, Posner JB. Paraneoplastic syndromes involving the nervous system. N Engl J Med 2003;349:1543-54 CrossRef Medline

16. Dalmau J, Rosenfeld MR. Autoimmune encephalitis update. Neuro Oncol 2014;16:771-78 CrossRef Medline

17. Graus F, Ariño H, Dalmau J. Paraneoplastic neurological syndromes in Hodgkin and non-Hodgkin lymphomas. Blood 2014;123: 3230-38 CrossRef Medline

18. Graus F, Keime-Guibert F, Reñe R, et al. Anti-Hu-associated para- 
neoplastic encephalomyelitis: analysis of 200 patients. Brain 2001; 124(pt 6):1138-48 CrossRef Medline

19. Shavit YB, Graus F, Probst A, et al. Epilepsia partialis continua: a new manifestation of anti-Hu-associated paraneoplastic encephalomyelitis. Ann Neurol 1999;45:255-58 CrossRef Medline

20. Keime-Guibert F, Graus F, Fleury A, et al. Treatment of paraneoplastic neurological syndromes with antineuronal antibodies (Anti$\mathrm{Hu}$, anti-Yo) with a combination of immunoglobulins, cyclophosphamide, and methylprednisolone. J Neurol Neurosurg Psychiatry 2000;68:479-82 CrossRef Medline

21. Rosenfeld MR, Eichen JG, Wade DF, et al. Molecular and clinical diversity in paraneoplastic immunity to Ma proteins. Ann Neurol 2001;50:339-48 CrossRef Medline

22. Dalmau J, Graus F, Villarejo A, et al. Clinical analysis of anti-Ma2associated encephalitis. Brain 2004;127(pt 8):1831-44 CrossRef Medline

23. Dalmau J, Gultekin SH, Voltz R, et al. Ma1, a novel neuron- and testis-specific protein, is recognized by the serum of patients with paraneoplastic neurological disorders. Brain 1999;122(pt 1):27-39 CrossRef Medline

24. Honnorat J, Cartalat-Carel S, Ricard D, et al. Onco-neural antibodies and tumour type determine survival and neurological symptoms in paraneoplastic neurological syndromes with $\mathrm{Hu}$ or CV2/CRMP5 antibodies. J Neurol Neurosurg Psychiatry 2009;80:412-16 CrossRef Medline

25. Vernino S, Tuite $\mathrm{P}$, Adler $\mathrm{CH}$, et al. Paraneoplastic chorea associated with CRMP-5 neuronal antibody and lung carcinoma. Ann Neurol 2002;51:625-30 CrossRef Medline

26. Gable MS, Sheriff $\mathrm{H}$, Dalmau J, et al. The frequency of autoimmune $\mathrm{N}$-methyl-D-aspartate receptor encephalitis surpasses that of individual viral etiologies in young individuals enrolled in the California Encephalitis Project. Clin Infect Dis 2012;54:899-904 CrossRef Medline

27. Titulaer MJ, McCracken L, Gabilondo I, et al. Treatment and prognostic factors for long-term outcome in patients with anti-NMDA receptor encephalitis: an observational cohort study. Lancet Neurol 2013;12:157-65 CrossRef Medline

28. Irani SR, Bera K, Waters P, et al. N-methyl-D-aspartate antibody encephalitis: temporal progression of clinical and paraclinical observations in a predominantly non-paraneoplastic disorder of both sexes. Brain 2010;133(pt 6):1655-67 CrossRef Medline

29. Kayser MS, Titulaer MJ, Gresa-Arribas N, et al. Frequency and characteristics of isolated psychiatric episodes in anti-N-methyl-d-aspartate receptor encephalitis. JAMA Neurol 2013;70:1133-39 CrossRef Medline

30. Dalmau J, Gleichman AJ, Hughes EG, et al. Anti-NMDA-receptor encephalitis: case series and analysis of the effects of antibodies. Lancet Neurol 2008;7:1091-98 CrossRef Medline

31. Dalmau J, Tüzün E, Wu HY, et al. Paraneoplastic anti-N-methyl-Daspartate receptor encephalitis associated with ovarian teratoma. Ann Neurol 2007;61:25-36 CrossRef Medline

32. Titulaer MJ, McCracken L, Gabilondo I, et al. Late-onset anti-NMDA receptor encephalitis. Neurology 2013;81:1058-63 CrossRef Medline

33. Johnson N, Henry C, Fessler AJ, et al. Anti-NMDA receptor encephalitis causing prolonged nonconvulsive status epilepticus. Neurology 2010;75:1480-82 CrossRef Medline

34. Lancaster E, Lai M, Peng X, et al. Antibodies to the GABA(B) receptor in limbic encephalitis with seizures: case series and characterisation of the antigen. Lancet Neurol 2010;9:67-76 CrossRef Medline

35. Höftberger R, Titulaer MJ, Sabater L, et al. Encephalitis and GABAB receptor antibodies: novel findings in a new case series of 20 patients. Neurology 2013;81:1500-06 CrossRef Medline

36. Boronat A, Sabater L, Saiz A, et al. GABA(B) receptor antibodies in limbic encephalitis and anti-GAD-associated neurologic disorders. Neurology 2011;76:795-800 CrossRef Medline

37. Petit-Pedrol M, Armangue T, Peng X, et al. Encephalitis with refractory seizures, status epilepticus, and antibodies to the GABAA receptor: a case series, characterisation of the antigen, and analysis of the effects of antibodies. Lancet Neurol 2014;13:276-86 CrossRef Medline

38. Graus F, Boronat A, Xifró X, et al. The expanding clinical profile of anti-AMPA receptor encephalitis. Neurology 2010;74:857-59 CrossRef Medline

39. Carr I. The Ophelia syndrome: memory loss in Hodgkin's disease. Lancet 1982;1:844-45 Medline

40. Mat A, Adler H, Merwick A, et al. Ophelia syndrome with metabotropic glutamate receptor 5 antibodies in CSF. Neurology 2013;80: 1349-50 CrossRef Medline

41. Malter MP, Helmstaedter C, Urbach $\mathrm{H}$, et al. Antibodies to glutamic acid decarboxylase define a form of limbic encephalitis. Ann Neurol 2010;67:470-78 CrossRef Medline

42. Grau-Rivera O, Sánchez-Valle R, Saiz A, et al. Determination of neuronal antibodies in suspected and definite Creutzfeldt-Jakob disease. JAMA Neurol 2014;71:74-78 CrossRef Medline

43. Paterson RW, Zandi MS, Armstrong R, et al. Clinical relevance of positive voltage-gated potassium channel (VGKC)-complex antibodies: experience from a tertiary referral centre. J Neurol Neurosurg Psychiatry 2014;85:625-30 CrossRef Medline

44. Irani SR, Michell AW, Lang B, et al. Faciobrachial dystonic seizures precede Lgil antibody limbic encephalitis. Ann Neurol 2011;69:892900 CrossRef Medline

45. Hiraga A, Kuwabara S, Hayakawa S, et al. Voltage-gated potassium channel antibody-associated encephalitis with basal ganglia lesions. Neurology 2006;66:1780-81 CrossRef Medline

46. Majoie $\mathrm{HJ}$, de Baets $\mathrm{M}$, Renier W, et al. Antibodies to voltage-gated potassium and calcium channels in epilepsy. Epilepsy Res 2006;71: 135-41 CrossRef Medline

47. Vincent A, Buckley C, Schott JM, et al. Potassium channel antibody-associated encephalopathy: a potentially immunotherapy-responsive form of limbic encephalitis. Brain 2004;127(pt 3):701-12 CrossRef Medline

48. Lancaster E, Huijbers MG, Bar V, et al. Investigations of caspr2, an autoantigen of encephalitis and neuromyotonia. Ann Neurol 2011; 69:303-11 CrossRef Medline

49. Blanc F, Ben Abdelghani K, Schramm F, et al. Whipple limbic encephalitis. Arch Neurol 2011;68:1471-73 CrossRef Medline

50. Badruddin A, Menon RS, Reder AT. 4-Aminopyridine toxicity mimics autoimmune-mediated limbic encephalitis. Neurology 2009;72: 1100-01 CrossRef Medline

51. Boeve BF, Bell DG, Noseworthy JH. Bilateral temporal lobe MRI changes in uncomplicated hypoglycemic coma. Can J Neurol Sci 1995;22:56-8 Medline

52. Baringer JR. Herpes simplex infections of the nervous system. Neurol Clin 2008;26:657-74, viii CrossRef Medline

53. Armangue T, Leypoldt F, Málaga I, et al. Herpes simplex virus encephalitis is a trigger of brain autoimmunity. Ann Neurol 2014;75: 317-23 CrossRef Medline

54. Schäbitz WR, Rogalewski A, Hagemeister C, et al. VZV brainstem encephalitis triggers NMDA receptor immunoreaction. Neurology 2014;83:2309-11 CrossRef Medline

55. Höftberger R, Armangue T, Leypoldt F, et al. Clinical neuropathology practice guide 4-2013: post-herpes simplex encephalitis: $\mathrm{N}$-methyl-Daspartate receptor antibodies are part of the problem. Clin Neuropathol 2013;32:251-54 CrossRef Medline

56. Karsan N, Barker R, O’Dwyer JP. Clinical reasoning: the "great imitator.” Neurology 2014;83:e188-96 CrossRef Medline

57. Vates GE, Chang S, Lamborn KR, et al. Gliomatosis cerebri: a review of 22 cases. Neurosurgery 2003;53:261-71, discussion 271 CrossRef Medline

58. Maia AC Jr, Malheiros SM, da Rocha AJ, et al. Stereotactic biopsy guidance in adults with supratentorial nonenhancing gliomas: role of perfusion-weighted magnetic resonance imaging. J Neurosurg 2004;101:970-76 CrossRef Medline

59. Sedlaczek O, Hirsch JG, Grips E, et al. Detection of delayed focal MR changes in the lateral hippocampus in transient global amnesia. Neurology 2004;62:2165-70 CrossRef Medline 
60. Cendes F. Febrile seizures and mesial temporal sclerosis. Curr Opin Neurol 2004;17:161-64 CrossRef Medline

61. Kim JA, Chung JI, Yoon PH, et al. Transient MR signal changes in patients with generalized tonicoclonic seizure or status epilepticus: periictal diffusion-weighted imaging. AJNR Am J Neuroradiol 2001; 22:1149-60 Medline

62. Cox JE, Mathews VP, Santos CC, et al. Seizure-induced transient hippocampal abnormalities on MR: correlation with positron emission tomography and electroencephalography. AJNR Am J Neuroradiol 1995;16:1736-38 Medline

63. Hatanpaa KJ, Blass DM, Pletnikova O, et al. Most cases of dementia with hippocampal sclerosis may represent frontotemporal dementia. Neurology 2004;63:538-42 CrossRef Medline

64. Caraballo RH, Reyes G, Avaria MF, et al. Febrile infection-related epilepsy syndrome: a study of 12 patients. Seizure 2013;22:553-59 CrossRef Medline

65. van Baalen A, Häusler M, Boor R, et al. Febrile infection-related epilepsy syndrome (FIRES): a nonencephalitic encephalopathy in childhood. Epilepsia 2010;51:1323-28 CrossRef Medline

66. Venkatesan A, Benavides DR. Autoimmune encephalitis and its relation to infection. Curr Neurol Neurosci Rep 2015;15:3 CrossRef

67. Castillo P, Woodruff B, Caselli R, et al. Steroid-responsive encepha- lopathy associated with autoimmune thyroiditis. Arch Neurol 2006; 63:197-202 CrossRef Medline

68. Hollowell JG, Staehling NW, Flanders WD, et al. Serum TSH, T(4), and thyroid antibodies in the United States population (1988 to 1994): National Health and Nutrition Examination Survey (NHANES III). J Clin Endocrinol Metab 2002;87:489-99 CrossRef Medline

69. Ferracci F, Carnevale A. The neurological disorder associated with thyroid autoimmunity. J Neurol 2006;253:975-84 CrossRef Medline

70. Song YM, Seo DW, Chang GY. MR findings in Hashimoto encephalopathy. AJNR Am J Neuroradiol 2004;25:807-08 Medline

71. Fujiki F, Tsuboi Y, Hashimoto K, et al. Non-herpetic limbic encephalitis associated with relapsing polychondritis. J Neurol Neurosurg Psychiatry 2004;75:1646-47 CrossRef Medline

72. Kumar N, Leep Hunderfund AN, Kutzbach BR, et al. A limbic encephalitis MR imaging in a patient with Behcet disease and relapsing polychondritis. AJNR Am J Neuroradiol 2009;30:E96 CrossRef Medline

73. Foidart JM, Abe S, Martin GR, et al. Antibodies to type II collagen in relapsing polychondritis. N Engl J Med 1978;299:1203-07 CrossRef Medline 